\title{
Synopsis of North American Amaranthaceæ. IV.
}

\author{
EDWIN B. ULINE AND WM. L. BRAY.
}

ALTERNANTHERA Forsk. Fl. Ægypt. Arab. 28. 1775.

Telanthera R. Br. (excl. Lithophila Sw.) Prodr. Fl. Nov. Holl. 1: 4I7. I8Io.

Mogiphanes Mart. Nov. Gen. et Sp. 2: 29. pl. 129, 134. 1826.

Plant mostly herbaceous, very variable in habit, with flowers clustered in dense terminal heads (as in Gomphrena) or axillary (as in Cladothrix), usually inconspicuous bracts, five free often unequal sepals, two to five stamens (five in ours) coalescent into a tube, alternating above with the staminodia, which are entire, pointed, and sometimes much reduced, or wider and more or less laciniate, with an ovate or sometimes obcordate compressed slightly winged ovary, and capitate stigma.

\section{*Staminodia simple.}

I. A. Repens (L.) Kuntze Rev. Gen. Pl. 540. I89I.

Achyranthes repens L. Sp. PI. 1: 205. 1753 .

Alternanthera Achyrantha R. Br. l. c. I810.

Stem prostrate, freely branching and forking, pubescent, I 5 to $50^{\mathrm{om}}$ long: leaves glabrate, orbicular to ovate, narrowed into a short petiole: glomerules axillary: flower slightly compressed: sepals lanceolate, with prominent median nerve, spiny-pointed, strongly unequal, the two short ones thickly pubescent with barbed hairs, fuscous: sterile filaments nearly equaling the fertile ones: utricle ovate, slightly compressed, encircled near the apex by an acute horizontal rim. - South Carolina, Georgia, throughout the gulf states in the region of the gulf, extending westward to Southern California and Chihuahua, and southward into Mexico as far as San Luis Potosi. Very near $A$. paronychioides in external aspect. Type unknown.

\section{* Staminodia short, dentate.}

2. A. PUngens HBK. Nov. Gen. et Sp. 2: 206. I8I7.

A. Achyrantha leiantha Seub.

A. echinata Sm. Rees Cycl. Suppl. no. ro.

Very similar to $A$. repens, but with larger leaves, echinate heads, the bracts and two of the perianth segments armed 3I-Vol. XX.-No. Io. 
with long aristæ and short wide dentate staminodia, which resemble those of $A$. paronychioides, but with fewer teeth.Native of southern Mexico and South America, but introduced at Mobile, Alabama. It is not known to be abundant anywhere.

Although this species is referred to by Moquin-Tandon among "Species non satis note," one of the specimens studied (Paraguay Morong 39) was identified by Dr. Britton at Kew, thus further confirming the decision already reached $e x$ char. The smaller-leaved forms approach $A$. repens very closely, but the staminodia character serves to give it specific rank. Type unknown.

3. A. Paronychioides St. Hil. Voy. Brés. 2: 43. I823.

Habit of $A$. repens, but less diffuse, with glabrate stem freely rooting at the nodes, narrower leaves with longer petioles, strongly compressed flowers, thin acute sub-equal pearly-white hairy sepals, much exceeding the utricle, short wide 3-dentate staminodia, and strongly compressed obcordate broadly margined utricle. - North Carolina, southward throughout the gulf states near the gulf. Native of the lowland tropics.

This species has been generally confused with $A$. repens, to which the specimens in our herbaria have mostly been referred. It may be recognized at once by its thin, white, exaristate sepals, although its more deep-seated distinction lies in the staminodia. This, and the next preceding, show more strikingly than any other forms the intimate relation of $\mathrm{Al}$ ternanthera to Telanthera, occupying a position directly intermediate between $A$. repens on the one hand, and $T$. ficoidea on the other, both in habit and in the character of the staminodia. Related also to $A$. pilosa of South America. Type unknown.

$$
\begin{aligned}
& \text { *** Staminodia long (equaling or surpassing the filaments), } \\
& \text { toothed or fringed. } \\
& + \text { Calyx sessile. } \\
& \text { 4. A. Kerberi, } \mathrm{n} . \mathrm{sp} .
\end{aligned}
$$

Diffuse, ascending, pubescent, with numerous joints, the lower ones putting out numerous long fibrous roots: leaves small ( $3^{\mathrm{cm}}$ long or less), narrowly spatulate, crowded: heads very small, sessile in the axils: bracts short, wide, deeply laciniate-margined: flowers small $\left(2^{\mathrm{mm}}\right)$ : sepals unequal, darkly 
colored on the back, scarious-margined: staminodia narrow, fringed at apex, equaling the filaments: mature utricle not seen.-State of Vera Cruz, Mexico. Our plant appears in every way to have grown in muddy or wet places. Cultivated forms from Washington and Philadelphia showing flower and bract characters identical with the type may have sprung originally from this form; but they differ strongly in plant habit, being glabrate, with larger and fewer leaves, and bearing no evidence of rooting nodes, although the lower part of these plants has not been seen. If there is such an indigenous form anywhere in existence, it undoubtedly belongs with $A$. Kerberi as a variety. The species may be recognized at once by its bracts.

Type (Atoyac, Vera Cruz, Kerber, May, I883) in herb. J. D. Smith. Cultivated specimens here referred to are in herb. Columbia College and Nat. herb.

5. A. maritima St. Hil. Voy. Brés. 2: 43. I 823.

Illecebrum maritimum Sprengel Syst. Cur. Post 4: 103. 1829.

Telanthera maritima Moq. 1. c. 364. 1849 .

Smooth and fleshy (black on drying): stem prostrate, angled, branching: leaves obovate, mucronate: flowers in small numerous axillary heads, triangular, closely sessile, leaving a wide depressed scar when removed: sepals rigid, indurate, ovate, acute, slightly aristate, about 5-ribbed, one-third longer than the wide keeled bracts: staminodia slightly longer than the filaments. - Southern Florida, where it has come in from the tropics by way of the West Indies. Type unknown.

\section{A. STEllata (Wats).}

Telanthera stellata Wats. Proc. Am. Acad. 21: 436. r886.

Herbaceous, ascending, branched, clothed throughout with short stellate pubescence: leaves ovate to lanceolate, acute, 2 to $5^{\mathrm{em}}$ long: heads sessile in the axils: flowers dorsally compressed: sepals unequal, the outer ones 3-nerved, rigid, pubescent with simple hairs, slightly aristate, somewhat recurved in maturity: staminodia exceeding the filaments.-Chihuahua and Sonora, Mexico.

Type (San Miguel, Chihuahua, Palmer 4, in I885) in herb. Gray, Columbia College, Nat. herb. and herb. J. D. Smith.

Telanthera stellata glabrata Rose in Nat. herb.

A. Stellata glabrata (Rose).

Plant glabrous throughout; otherwise not differing from the species.-Sonora, Mexico. 
Type (Alamos, Sonora, Palmer $660 a$ in 1890 ) in Nat. herb. 7. A. PHiloxeroides (Mart.) Griseb. in Goett. Abh. 24: 36. 1879.

Bucholzia philoxeroides Mart. Beitr. Amarant. 107. 1825.

This species has been found at Pensacola, Florida (Mohr 26), and at Coosan, South Carolina (Cohen in 1885 ), where in both cases it is probably adventive.

\section{$+\div$ Calyx pedicellate.}

8. A. Brasiliana (L.) Kuntze Rev. Gen. Pl. 537. 1891.

Gomphrena Brasiliana L. Amœn. Acad. 4: 3 10. 1759.

Gomphrena patula Wendl. Beob. 43. I798.

Mogiphanes straminea Mart. Nov. Gen. et Sp. Bras. 2: 35. pl. 135. 1826.

Mogiphanes ramosissima Mart. 1. c. 3I. pl. L30. 1826.

Philoxera Brasiliana Smith in Rees Cycl. 5: 27. -.

Celosia altissima Salzm. ex. Moq. 1. c. 381. 1849.

Telanthera Floridana Chapm. Fl. S. U. S. 383 . 1883.

Herbaceous or suffrutescent, mostly erect, slender, elongated, remotely jointed, forking or branched, often swollen at the nodes, from glabrate to villous: leaves small ( 1 to $7^{\text {om }}$ long), ovate to lanceolate, acuminate, short petioled: heads ovate or sometimes cylindrical in maturity, long peduncled: bracts short, persistent: flowers $4^{\mathrm{mm}}$ long, 3 times the length of the bracts, deciduous, raised on a short dilate 5-angled pedicel: sepals pubescent, yellowish: utricle crowned with a narrow rim as in $A$. repens.-Florida, where it has crept in from the lowland tropics.

Type unknown. Chapman's types of T. Floridana are in herb. Columbia College, and herb. J. D. Smith.

A careful test has been made with reference to the validity of the pedicels as diagnostic characters. It is found that the dilate, 5-lobed pedicels of this species are quite distinct and constant, having been seen nowhere else in the large number of both native and tropical specimens studied except in $\mathrm{Al}$ ternanthera rosea (Morong) U. \& B., which, unlike T. ramosissima Moq., has other peculiarities sufficient to keep it apart. Dr. Kuntze, disregarding this fact, has united certain species under $A$. bicolor $\mathrm{OK} 1$. c., which on this basis are seen to be clearly and constantly distinct. Moreover, his observations on the color of the flowers, even if correct, do not seem to offer sufficient ground for uniting so many species on that character alone. It is artificial in that he has relegated floral 
structure to a place of secondary importance. While there is no question that Moquin-Tandon has multiplied species far too freely, we are unwilling to accept this color basis as a satisfactory solution. Again, why has he not followed the law of priority and adopted the earliest published name from among the merged species, instead of naming de novo?

\section{A. Brasiliana Moquini (Webb.).}

Telanthera Moquini Webb. ex Moq. 1. c. 379. 1849 .

Plant glabrate, suffruticose, with ovate leaves larger and wider than in the species, and slender 5-angled pedicel. Florida Keys.

Type (Key West, Florida, Blodgett,) in herb. Columbia College. Only one Florida specimen was seen, but it conforms closely with authenticated South American specimens.

A. GRACILIS (Mart. et Galeot.) occurs as far north as Tampico, Mexico, but has not yet been reported from our territory.

A. FICOIDEA RADICANS R. \& S. (incl. T. polygonoides Moq.) was said by Moquin-Tandon to have been found in Carolina. Chapman has adopted this, on the strength of which he includes $T$. polygonoides in his Southern Flora. The very close resemblance of this variety (ex descr.) to the indigenous $A$. repens and $A$. paronychioides of that region, together with the fact that $T$. polygonoides has not otherwise been known north of the West Indies, make it quite probable that Moquin's plant was one of the above species.

Telanthera polygonoides brachiata (Schrad.) Moq. 1. c.= Alternanthera Ficoidea Brachiata (Schrad.).

Mogiphanes rosea Morong in Ann. N. Y. Acad. Sci. 7:I 893 = AlternantHERA ROSEA (Morong).

Telanthera Tuerckheimii Vatke ined.= GOMPHRENA Tuerckheimi (Vatke) U. \& B. in Bot. Gaz. 20: r6i. 1895.

Lake Forest University. 


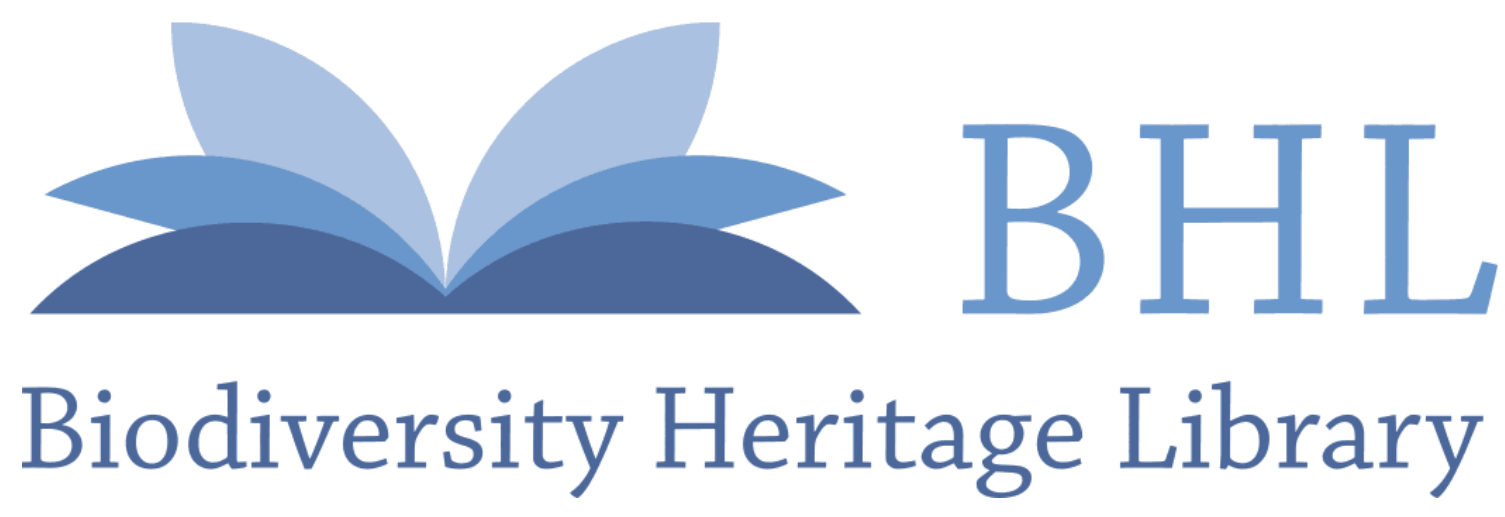

Uline, Edwin Burton. 1895. "Synopsis of North American Amaranthaceæ. IV." Botanical gazette 20(10), 449-453. https://doi.org/10.1086/327249.

View This Item Online: https://www.biodiversitylibrary.org/item/88066

DOI: https://doi.org/10.1086/327249

Permalink: https://www.biodiversitylibrary.org/partpdf/222526

\section{Holding Institution}

Missouri Botanical Garden, Peter H. Raven Library

\section{Sponsored by}

Missouri Botanical Garden

\section{Copyright \& Reuse}

Copyright Status: Public domain. The BHL considers that this work is no longer under copyright protection.

This document was created from content at the Biodiversity Heritage Library, the world's largest open access digital library for biodiversity literature and archives. Visit BHL at https://www.biodiversitylibrary.org. 